\title{
Anaerobic co-digestion of mixed activated sewage sludge and fruit and vegetable waste on two-stage digester stability
}

\author{
Herald Wilson Ambrose ${ }^{1}$, Ligy Philip ${ }^{2}$, G.K. Suraishkumar ${ }^{2}$, and Tushar Sen ${ }^{3}$ \\ ${ }^{1}$ Curtin University Bentley Campus \\ ${ }^{2}$ Indian Institute of Technology Madras \\ ${ }^{3}$ Edith Cowan University - Joondalup Campus
}

May 5, 2020

\begin{abstract}
Co-digestion of mixed waste activated sludge (MWAS) and fruit and vegetable waste (FVW) was studied in a two-stage (thermophilic followed by mesophilic) semi-continuous anaerobic digestion to evaluate anaerobic digester performance and stability. A mixing ratio of $75 \%$ MWAS and $25 \%$ FVW showed a 1.6-fold increase in overall methane yield and achieved 0.38 FOS/TAC ratio (volatile fatty acids to alkaline buffer capacity) compared to mixture of $50 \%$ MWAS and $50 \%$ FVW. Application of hybrid (MW-H2O2) pretreatment in the former mixing ratio increased sludge solubilisation by $33 \%$ and consequently enhanced overall methane yield by 2.17 -fold. The treated digester showed increased process stability with a FOS/TAC ratio of 0.26 as a consequence of buffer capacity offered by released biopolymers during pre-treatment. The generation of superoxide radicals during digestion was studied and found to negatively correlate with sludge bioactivity. Two-stage digestion also minimizes the issue of high acidification due to co-digestion involving FVW.
\end{abstract}

\section{Introduction:}

Fruit and vegetable wastes (FVW) constitute one of the major organic wastes production from different sources and in Western Australia, around 30\% of production end up as waste ${ }^{1}$. The disposal of FVW in large quantities in landfills is difficult due to its high biodegradable organic content and subsequent environmental impacts ${ }^{2,3}$. On the other hand, anaerobic digestion has been proven to be an efficient technology for the treatment of organic solid wastes and energy recovery. Therefore, one of the alternatives to landfills of these large quantities of FVW is utilization and valorization of the residue in the production of biogas and high-quality organic-rich digestate through anaerobic co-digestion process. Anaerobic digestion involves biochemical degradation of organic wastes by microorganisms in an anoxic environment with the production of methane and carbon dioxide as major gases. In recent years, various researches are undertaken to address the challenges and process optimization of anaerobic digestion for its efficient application in waste management ${ }^{4}$. Anaerobic digestion involves four major biochemical reactions, viz, hydrolysis, acidogenesis, acetogenesis and methanogenesis; separation of respective microbial communities and facilitating them with optimum conditions help to reduce the limitations of anaerobic digestion ${ }^{5}$.

Fermentation of FVW in anaerobic digestion faces severe acidification issues that inhibit the growth of methanogenic population due to its high sugar content and volatile solids (VS) fraction ${ }^{6}$. Moreover, the high $\mathrm{C} / \mathrm{N}$ ratio of FVW leads to nitrogen depletion in anaerobic digestion and requires an additional substrate that can sustain fermentation efficiency ${ }^{3}$. For these reasons, co-digestion of FVW with complementary substrates such as kitchen waste, agricultural waste and sewage sludge have been tried out ${ }^{3}$. The co-digestion of sewage sludge with FVW have shown improvement in biogas yield and agronomic digestate quality ${ }^{7,8}$. Furthermore, various authors have investigated two-stage anaerobic digestion under mesophilic conditions to improve 
the biogas production and sustain high OLR (organic loading rate) ${ }^{9-11}$. Phase separation of microbial population offers better control over the respective phases, increases the specific activity of methanogens and also improves the suspended solids removal efficiency ${ }^{12}$. Besides, different reactor configurations for phase separation of the acidogenic and methanogenic population have also been studied ${ }^{13,14}$. In most of the studies, an acidifier (pre-methanizer) reactor helps in stabilization of methanogenic population in methanizer reactor while handling solid wastes with high organic content. And, the overall retention time can also be reduced in such two-phase systems compared to conventional anaerobic digestions.

Besides the novelties of reactor configurations and co-digestions, various pre-treatments of solid wastes have also been studied to overcome the rate-limiting hydrolysis step and enhance anaerobic digestion performance 15. Pre-treatments breakdown macromolecular structures and facilitate sludge hydrolyzation. In the case of polysaccharide-rich solid wastes (FVW), the lignin barrier present in skins and seeds makes bacterial hydrolysis difficult ${ }^{16}$. Among various FVW pre-treatments, thermal hydrolysis has been established as a prominent pre-treatment technique with enhanced sludge solubilisation, digestion performance and improved dewaterability ${ }^{17,18}$. Recently, microwave enhanced advanced oxidation process has gained huge research attention as a pre-treatment technique for its effectiveness in hydrolyzation, biogas production and effluent digestate quality ${ }^{19,20}$. The synergetic effect of microwave and hydrogen peroxide $\left(\mathrm{MW}-\mathrm{H}_{2} \mathrm{O}_{2}\right)$ have been shown to improve sludge solubilisation and also significantly affect biogas production from activated sludge samples ${ }^{20-22}$. Apart from the initial sludge solubilisation through thermal effect, microwave enhanced advanced oxidation process $\left(\mathrm{MW}-\mathrm{H}_{2} \mathrm{O}_{2}\right)$ also imparts oxidative stress on the microbial population mediated by reactive oxygen species (ROS) ${ }^{22,23}$. During the oxidation process, highly reactive oxidative intermediates such as hydroxyl $[\mathrm{OH}]$ and superoxide radicals $\left[\mathrm{O}_{2}^{-}\right]$are generated, that oxidize the organic pollutants and also intermediate intracellular oxidative stress in the microbial population ${ }^{23}$. Evaluation of such oxidative intermediates helps us to understand the effect of hybrid $\left(\mathrm{MW}-\mathrm{H}_{2} \mathrm{O}_{2}\right)$ pre-treatment on microbial sludge activity and expands the knowledge on oxidative stress in sludge microenvironment.

Previous studies on hybrid $\left(\mathrm{MW}-\mathrm{H}_{2} \mathrm{O}_{2}\right)$ pre-treatment were mainly focused on anaerobic digestion of activated sludge samples under mesophilic condition. The effects of hybrid $\left(\mathrm{MW}-\mathrm{H}_{2} \mathrm{O}_{2}\right)$ pre-treatment differs dependent on the nature of the feedstock. And also, hybrid treatment of activated sludge under acidic conditions has shown improved methane production in mesophilic anaerobic digestion ${ }^{20}$. The acidic nature of FVW has the potential to enhance the effects of hybrid pre-treatment in anaerobic co-digestion with activated sludge. Hence, in the present study, the impact of hybrid $\left(\mathrm{MW}-\mathrm{H}_{2} \mathrm{O}_{2}\right)$ pre-treatment on anaerobic digestion efficiency of FVW co-digested with mixed activated sludge is studied. Besides, a two-stage anaerobic digester was operated to separate hydrolysis-acidogenesis in phase I (thermophilic condition) and methanogenesis in phase II (mesophilic condition). Two different mixing ratios of FVW and mixed activated sludge were evaluated based on biomethanation and process stability, followed by the studies of hybrid $\left(\mathrm{MW}-\mathrm{H}_{2} \mathrm{O}_{2}\right)$ pre-treatment. The impact of hybrid $\left(\mathrm{MW}-\mathrm{H}_{2} \mathrm{O}_{2}\right)$ pre-treatment on anaerobic digestibility of co-digestion is evaluated based on biogas production, biogas quality, sludge hydrolyzation and process stability. In addition, the effects of pre-treatment on the oxidative status of anaerobic digestion mediated by superoxide radicals were studied along with sludge bioactivity to establish knowledge on reactive oxygen species in anaerobic digestion.

\section{Materials and Methods:}

\subsection{Sampling and characterization:}

The Mixed Waste Activated Sludge (MWAS) used in this study was withdrawn from mixed sludge sampling point before anaerobic digester at Beenyup Wastewater Treatment Plant (BWWTP), Western Australia. The MWAS sample consists of raw primary sludge (PS) and thickened excess activated sludge (TEAS) mixed in the ratio 65:35, as it is available in the plant. The digested sludge (DS) was collected from the sampling port of anaerobic digester of the same treatment plant. The fruit and vegetable waste (FVW) used in the current study was prepared by blending the components given in Table 1. MWAS and FVW were mixed in the ratio 1:1 and 3:1 (on a total solids basis). All the samples were freshly collected/ prepared and used for experiments to avoid any microbial contamination during storage. 


\subsection{Experimental Set-up}

A two-stage (phase I followed by phase II) anaerobic digester set-up consisting of two 1L reactors connected in series with the feed sludge is used for the current study. The set-up consists of a phase-I reactor maintained at a constant thermophilic condition $\left(55 \pm 2{ }^{\circ} \mathrm{C}\right)$ and a phase-II reactor maintained at a constant mesophilic condition $\left(37 \pm 2{ }^{\circ} \mathrm{C}\right)$. The reactors are maintained at their respective temperatures by jacket heating system and monitored continuously. Phase I reactor carries out hydrolysis-acidogenesis, followed by methanogenic phase II reactor. The substrate was transferred from phase-I to phase-II on day 3, based on monitoring of $\mathrm{pH}$ and VFA accumulation. Two such two-stage set-ups were developed and operated semi-continuously for the current study. Two- different feedstocks $\mathrm{F}_{1}$ (1:1, MWAS: FVW) and $\mathrm{F}_{2}(3: 1$, MWAS: FVW) were produced and evaluated for anaerobic process stability. Followed by, a study on hybrid $\left(\mathrm{MW}-\mathrm{H}_{2} \mathrm{O}_{2}\right)$ pre-treatment on anaerobic co-digestion with feedstock $\mathrm{F}_{2}$. The reactors were provided with liquid and gas sampling ports. The biogas generated was collected in inverted cylinders with water displacement technique.

\subsection{Sludge pre-treatment}

The feedstocks were subjected to combined microwave and hydrogen peroxide treatment. The sludge was initially heated at $80{ }^{\circ} \mathrm{C}$ by microwave irradiation at $660 \mathrm{~W}$ for 2 minutes to curtail catalase activity in the microbial fraction of MWAS; catalase breaks down $\mathrm{H}_{2} \mathrm{O}_{2}$ into water and molecular oxygen inhibiting the oxidative effect of pre-treatment ${ }^{24}$. Followed by, the addition of hydrogen peroxide $\left(1 \% \mathrm{w} / \mathrm{w} \mathrm{H}_{2} \mathrm{O}_{2} / \mathrm{TS}\right)$ at room temperature with constant mixing. The sludge was again microwave irradiated at $660 \mathrm{~W}$ for 3 minutes in a laboratory-scale microwave oven, with an intermittent break to avoid water evaporation. The treated and untreated mixed sludge samples were inoculated with 10\% DS making up to an operating volume of 500 $\mathrm{ml}$.

\subsection{Analytical methods:}

The sludge samples were collected periodically from the two-stage anaerobic digesters and subjected to basic characterization such as $\mathrm{pH}$, temperature and TDS/ conductivity immediately after collection. The characterization was done using WP-90 conductivity/ TDS-pH/ temperature meter. Specific intracellular superoxide radicals $\left[\mathrm{O}_{2}^{-}\right]$are short living reactive intermediates, so its measurement was done immediately after collection of the sample. $\left[\mathrm{O}_{2}^{-}\right]$characterization from sludge samples was done using dihydroethidium (DHE) dye ${ }^{23}$. Briefly, $1 \mathrm{ml}$ of the sample was collected and centrifuged at $5000 \mathrm{rpm}$ for 10 minutes at 4 ${ }^{\circ} \mathrm{C}$ to isolate the pellet. The pellet was washed and suspended in $1 \mathrm{ml}$ of phosphate buffer $(\mathrm{pH} 7.4)$. DHE was added to a final concentration of $10 \mu \mathrm{M}$ and incubated in dark for 30 minutes at $37{ }^{\circ} \mathrm{C}$. The fluorescent dye DHE is freely permeable across cell membranes and reacts with the intracellular superoxide radicals and produce a fluorescent product that can be measured in a fluorescent spectrometer (excitation: 485/20, emission: 590/35). Standard plot for superoxide concentration was plot using Xanthine/Xanthine Oxidase system ${ }^{23}$. Total and soluble chemical oxygen demand (tCOD and sCOD) measurements were done using $\mathrm{HACH}$ COD reagent, followed by colorimetric analysis in ORION UV- spectrometer. The soluble fraction of sludge was acquired by centrifugation of samples at $5000 \mathrm{rpm}$ for 10 minutes at $4{ }^{\circ} \mathrm{C}$, followed by filtration of supernatant using a $0.45 \mu \mathrm{m}$ Whatman filter paper. Total solids and volatile solids (TS and VS) were measured using standard APHA protocol ${ }^{25}$. Volatile fatty acids (VFAs) and total alkalinity were measured using direct titration technique ${ }^{26}$. Sludge bioactivity was measured using TTC-DHA (Triphenyl tetrazolium chloride- dehydrogenase) activity. TTC-DHA activity involves the reduction of triphenyl tetrazolium chloride (TTC) to formazan (TF) by free electrons, that are produced as a result of oxidation reactions catalyzed by dehydrogenase enzymes ${ }^{27}$. The TTC-DHA activity was measured using the redox-sensitive tetrazolium dye, according to TTC- DHA assay ${ }^{28}$. The red formazan salt produced during the assay was deducted colorimetrically at $485 \mathrm{~nm}$. Protein and carbohydrate characterization were done using Bicinchoninic Acid method $^{29}$ and phenol-sulfuric acid method ${ }^{30}$ respectively, in 96-well microtiter plates. The biogas produced was measured using a GA 2000 gas analyzer.

\subsection{Calculation}

The VS reduction percentage was calculated based on the inlet and outlet VS concentration of the two-stage 
anaerobic digester based on the following equation

Volatile solids $(\mathrm{VS})$ reduction $\%=\frac{\text { VSinlet }- \text { VSoutlet }}{\text { VSinlet }} \times 100$ equation $(1)$

The specific intracellular concentration of superoxide radicals is calculated based on the following equation.

Specific intracellular superoxide radical, $s\left[\mathrm{O}_{2}^{-}\right]$(umoles $\left./ g T S\right)=\frac{\text { Superoxide }(u m o l e s / l)}{\text { Total solids }\left(\frac{g}{l}\right)}$ equation (2)

The process stability of anaerobic digestion was measured by FOS/TAC ratio, as per the following equation.

FOS $/ T A C=\frac{\text { Volatile fatty acids }\left(\frac{\mathrm{mg}}{\mathrm{l}}\right)}{\text { Alkalinity }\left(\frac{\mathrm{mg}}{\mathrm{l}}\right)}$ equation (3)

\section{Results and Discussion:}

\subsection{Effect of mixing ratio in anaerobic digestibility of FVW in co-digestion:}

Various authors have investigated the efficiency of co-digestion of sewage sludge with fruit and vegetable waste 3 . The higher COD, TS and VS content of FVW compared to MWAS (Table 2), assures higher biodegradable organic content and makes it suitable for anaerobic digestion. However, the high VS content of FVW favors quick hydrolysis, consequently followed by increased acidification which could threaten methanogenesis ${ }^{31}$. In the current study, the mixing ratio of Beenyup mixed waste activated sludge with fruit and vegetable waste were optimized in two-stage anaerobic digesters at constant HRT. Co-digestion (3:1) achieved 1.6 times higher cumulative methane yield compared to co-digestion (1:1) (Figure 1a). Two-stage anaerobic digestion accelerates rate-limiting hydrolysis step in the thermophilic phase, followed by the methanogenic population in the mesophilic phase. The $\mathrm{CH}_{4} / \mathrm{CO}_{2}$ ratio in both digestions was observed to be less than 0.5 during the initial thermophilic phase indicating a higher build-up of carbon dioxide in the reactors (Figure 1b). At higher organic loading, the addition of FVW increases the production of carbon dioxide, hydrogen and acetate production by acidogenic microbial population in the thermophilic phase ${ }^{32}$. No significant amount of methane production was observed in co-digestion (1:1) signaling unsuitable conditions for methanogenic population inside the digester. Co-digestion (3:1) achieved 9.1-fold higher methane production during the initial thermophilic phase, as a courtesy of improved $\mathrm{pH}$ stability. Moreover, the reduction of organic loading by changing the FVW fraction in sludge feedstock didn't significantly curb the accumulating carbon dioxide in the initial phase. However, transfer of substrate to phase II, increased methane production by 1.49 -fold in co-digestion (3:1). Besides, during this phase methane percentage increased significantly and a greater reduction of carbon dioxide compared to co-digestion (1:1) was observed (Figure 1b). This could be due to the increased stability achieved in mesophilic phase-II with improved balance of nutrients.

Furthermore, the FVW fraction and OLR have been reported to have a significant effect on biogas production and process stability in co-digestion with sludge ${ }^{33-35}$. The HRT (Hydraulic retention time) of the thermophilic phase was 2 days in both the systems and the corresponding OLR were $13 \mathrm{gVS} /$.day and 11.5 gVS/l.day in co-digestion (1:1) and (3:1) respectively. The VS removal percentage was almost similar in both the systems during the thermophilic phase. However, a 33\% higher VS removal was observed in co-digestion (3:1) compared to co-digestion (1:1), in the mesophilic phase II. The overall OLR of the digestions were $1.3 \mathrm{gVS} /$ l.day and $1 \mathrm{gVS} /$ l.day in co-digestion (1:1) and co-digestion (3:1), respectively. Di Maria et al., reported a higher OLR $\left(>2 \mathrm{kgVS} / \mathrm{m}^{3}\right.$.day) with an excessive fraction of FVW in co-digestion with waste mixed sludge resulted in microorganism washout and decrease in biogas production under mesophilic condition ${ }^{8}$. Whereas, in the current study we observed that $50 \%$ of FVW in co-digestion with sludge leading to an OLR of $1.3 \mathrm{gVS} /$ l.day itself had a detrimental effect on the methanogenic population under thermophilic condition. Besides, the reduction of OLR to $1 \mathrm{gVS} /$ l.day with $25 \%$ FVW showed improvement in overall process performance and biogas production.

Even though thermophilic condition favors hydrogenotrophic methanogens (methane production from $\mathrm{H}_{2}$ and $\mathrm{CO}_{2}$ ), poor methanogenesis was observed in phase I anaerobic digestion due to the accumulation of VFAs and poor buffering capability of FVW (Figure 2a and b). FOS/TAC is the ratio of volatile organic acid to alkaline buffer capacity, and it is often widely used to assess the process stability of an anaerobic digester. Literature studies report that FOS/TAC values of stable anaerobic digestion lie in the range of $0.2-0.6^{6,36,37}$. 
FOS/TAC values beyond 0.6 indicate unsuitable operating conditions for anaerobic microorganisms and results in a decrease in biogas production. In the current study, the average values of FOS/TAC in phase I thermophilic reactor were 1.91 and 1.1 in co-digestion (3:1) and co-digestion (1:1) respectively (Figure $2 \mathrm{~b}$ ). Considering that waste activated sludge is characterized with low $\mathrm{C} / \mathrm{N}$ ratios and high buffer capacity, increase in WAS fraction in co-digestion has certainly improved the FOS/TAC ratio ${ }^{38}$. As the thermophilic condition has higher organic degradation rates, along with increased organic loading, the phase-I anaerobic digestion resulted in accumulation of VFAs resulting in unstable anaerobic digestion in co-digestion (1:1) (Figure 2a). However, transfer of substrate to Phase-II significantly improved the stability of anaerobic digestion and resulted in average FOS/TAC values of 0.51 and 0.38 in co-digestion (3:1) and co-digestion (1:1) respectively (Figure $2 \mathrm{~b}$ ). Improved process efficiency was observed in co-digestion (3:1) in phase-II, with $21 \%$ higher reduction in VFAs and 1.6-fold increase in methane yield compared to co-digestion (1:1), at the end of 20 days of HRT.

\subsection{Effect of hybrid $\left(\mathrm{MW}-\mathrm{H}_{2} \mathrm{O}_{2}\right)$ pre-treatment in anaerobic digestibility of $\mathrm{FVW}$ in co- digestion:}

\subsubsection{Biogas production}

The efficiency of hybrid $\left(\mathrm{MW}-\mathrm{H}_{2} \mathrm{O}_{2}\right)$ feed sludge pre-treatment in enhancing anaerobic digestibility of co-digestion (MWAS+FVW) was studied in two-stage anaerobic digesters with the co-digestion ratio 3:1 (MWAS: FW). Microwave enhanced advanced oxidation process is an effective method in improving sludge solubilisation and consequently promotes biomethanation in waste activated sludge ${ }^{20}$. In the current study, hybrid (MW- $\mathrm{H}_{2} \mathrm{O}_{2}$ ) pretreatment significantly improved the biogas production and biogas quality in codigestion (3:1). The pretreated co-digestion (3:1) yielded 2.17-fold higher cumulative methane yield compared to untreated co-digestion (3:1) at the end of 20 days (Figure 1a). 2.91-fold higher methane production was achieved in thermophilic phase I of treated digester compared to untreated co-digestion (3:1). Besides, the biogas quality achieved in pre-treated sludge fed thermophilic digester was also significantly improved. On an average, treated phase I digester maintained $0.73 \mathrm{CH}_{4} / \mathrm{CO}_{2}$ ratios, whereas untreated digester suffered a low $0.21 \mathrm{CH}_{4} / \mathrm{CO}_{2}$ ratio (Figure $1 \mathrm{~b}$ ). On average, the phase-II biogas quality was improved with $\mathrm{CH}_{4} / \mathrm{CO}_{2}$ ratio of 1.55 in the treated digester, whereas untreated digester maintained 1.05.

Literature reports suggest that pre-treatments enhance anaerobic digestibility of FVW by accelerated hydrolyzation and breakdown of macromolecules ${ }^{3}$. Zhou et al, reported $115 \%$ increased anaerobic digestion performance and a 2-fold increase in digestion rate in thermally pre-treated co-digestion involving FVW compared to untreated digestion ${ }^{17}$. Quite recently, Shanthi et al, reported a $31 \%$ increase in biomethane yield in anaerobic digestion of FVW by combined (Dimethyl sulfoxide and ultrasonication) pretreatment ${ }^{16}$. Moreover, combined $\left(\mathrm{MW}-\mathrm{H}_{2} \mathrm{O}_{2}\right)$ pretreatment achieved an 8.72-fold increase in biogas production in anaerobic digestion of dairy wastewater ${ }^{20}$. The study also reported that combined ( $\mathrm{MW}-\mathrm{H}_{2} \mathrm{O}_{2}$-acid) pretreatment enhanced biogas production by 9.78 -fold, emphasizing the efficiency of combined treatment under acidic conditions. In the current study, the hybrid $\left(\mathrm{MW}-\mathrm{H}_{2} \mathrm{O}_{2}\right)$ pre-treated FVW co-digestion outperformed untreated digestion in both phases, making it be an appropriate pre-treatment technique for organic content-rich substrate. The untreated digestion showed a lag phase in biogas production during the thermophilic condition, whereas the treated digestion exhibited an exponential increase due to the soluble substrate available for the methanogenic population (Figure 1a). Most of the studies on pretreated anaerobic digestion, suggests that enhancement in biogas production is mostly due to the initial hydrolyzation achieved through pretreatment. Besides, phase separation in anaerobic digestion of FVW has been highly efficient due to the process stability and enhanced biomethanation ${ }^{31,39}$. Moreover, the improved methane production in both phases in treated digestion could be due to hydrogenotrophic and syntrophic acetate oxidizing microbes, as the latter has a significant effect at high VFA (>1000 mg/l) concentration $^{34}$.

\subsubsection{Sludge solubilisation and digester performance}

In the current study, the FVW was initially blended and homogenized to facilitate anaerobic digestion. Consequently, the mixed co-digested sludge achieved an initial COD solubilisation of $22 \%$ which was 2.2 
folds higher than pure MWAS anaerobic digestion reported in our previous study ${ }^{22}$. Application of hybrid $\left(\mathrm{MW}-\mathrm{H}_{2} \mathrm{O}_{2}\right)$ pre-treatment on mixed sludge further enhanced COD solubilisation by $33 \%$ facilitating easily available soluble organic content for subsequent utilization by acidogenic microbial population (Figure 3 and 4). The microwave enhanced oxidation process exhibits oxidative stress on anaerobic digestion by the generation of reactive oxygen species (ROS), that oxidize organic microbial fractions and causes cell wall breakdown ${ }^{23}$. The efficiency of hybrid $\left(\mathrm{MW}-\mathrm{H}_{2} \mathrm{O}_{2}\right)$ pre-treatment on optimum sludge solubilisation of organic compounds without the formation of recalcitrant products is very much dependent on the dosage of hydrogen peroxide ${ }^{24,40}$. An optimum sludge solubilisation involves the disintegration of EPS matrix and dissolution of proteins and carbohydrates fraction of activated sludge, without the formation of melanoidins through Maillard reaction ${ }^{23}$. In the current research, the dissolution of proteins and carbohydrates was consistent with the COD solubilisation as per the equivalent relationships: $1.5 \mathrm{gCOD} / \mathrm{gProtein}$ and 1.06 gCOD/ gCarbohydrate ${ }^{41}$. Accordingly, the soluble protein was observed to be $18.35 \%$ and $39.40 \%$ of sCOD in the untreated and treated digester respectively; soluble carbohydrate constituted $40 \%$ and $42 \%$ of sCOD in the untreated and treated digester, respectively. As the feedstock constitutes $25 \%$ FVW, the solubilized fraction of carbohydrates was observed to be significantly higher than the proteins (Figure 4). Application of pretreatment enhanced protein solubilisation by $177 \%$ and carbohydrate solubilisation by $18 \%$ (Figure 4). This indicates that the application of $\left(\mathrm{MW}-\mathrm{H}_{2} \mathrm{O}_{2}\right)$ pre-treatment affects EPS disintegration more than the organic constituents of FVW, as EPS constitutes more than $43 \%$ protein and $10-18 \%$ of carbohydrate in its composition ${ }^{40}$. The higher COD solubilisation and EPS disintegration would accelerate the subsequent anaerobic digestion in the two-stage digesters.

The digester performance of the two-stage anaerobic digestion with and without hybrid treatment was compared with VFA accumulation and FOS/TAC ratio (Figure 2). VFAs are common inhibitors of anaerobic digestion and their accumulation within the digesters lead to process instability. In the current research, no significant difference in the VFA accumulation was observed in the initial thermophilic phase of both twostage systems (Figure 2a). However, the FOS/TAC ratio was 77\% higher in the untreated digester compared to the treated digester, during this phase (Figure $2 b$ ). The improved digester performance in the thermophilic phase of treated digester could be due to the buffering capability of microbial intracellular compounds released during the hybrid $\left(\mathrm{MW}-\mathrm{H}_{2} \mathrm{O}_{2}\right)$ pretreatment. Zhou et al, reported a similar phenomenon, wherein despite an increase in VFA accumulation by thermal hydrolysis pre-treatment, the digester maintained stable $\mathrm{pH}$ and VFA/alkalinity levels compared to the untreated digester, indicating the buffering ability achieved during the pretreatment ${ }^{17}$. Besides, the increased nitrogen mineralization with co-digestion (3:1) along with the pre-treatment could also increase the buffering capability of the system ${ }^{42}$. The mesophilic phase II anaerobic digestion significantly improved FOS/TAC ratio in both the systems with the treated digester achieving an average of 0.26 , which is well within the acceptable range of stable anaerobic digestion. Although, Di Maria et al, reported stable anaerobic digestion with FOS/TAC value $<0.1$ in a co-digestion of FVW with sludge under mesophilic conditions ${ }^{8}$.

\subsubsection{Oxidative status and sludge activity}

Microwave enhanced advanced oxidation process is known for the destruction of microbial cell walls and oxidation of numerous recalcitrant organic pollutants present in wastewater through the formation of hydroxyl radicals $[\mathrm{OH}]^{43}$. An optimum concentration of $\mathrm{H}_{2} \mathrm{O}_{2}$ pretreatment leads to the formation of $[\mathrm{OH}]$ radicals, the highly reactive and strongest oxidant among $\mathrm{H}_{2} \mathrm{O}_{2}$ derivatives; higher concentration of $\mathrm{H}_{2} \mathrm{O}_{2}$ might lead to the formation of perhydroxyl radicals $\left[\mathrm{HO}_{2}\right]$, which is less reactive and decreases the release of soluble organics $^{20}$ according to equation 4 .

$\mathrm{H}_{2} \mathrm{O}_{2}+\mathrm{OH} \leftrightarrow \mathrm{HO}_{2}+\mathrm{H}_{2} \mathrm{O}$ equation (4) Apart from the 'Fenton'- driven hydroxyl radicals, there is another short-living oxidative intermediate, namely, superoxide $\left[\mathrm{O}_{2}^{-}\right]$that are prominent in oxidation reactions involving hydrogen peroxide ${ }^{23}$.

The importance of anaerobic free radical formation has been underestimated in the field of wastewater treatment. Anaerobic microorganisms can encounter free radical formation even under strictly anaerobic/microaerobic conditions, and they have developed radical scavenging mechanisms (i.e, SOR; superoxide 
oxidoreductases) to neutralize such radicals ${ }^{44}$. In the current study, the oxidative stress induced by hybrid $\left(\mathrm{MW}-\mathrm{H}_{2} \mathrm{O}_{2}\right)$ pretreatment was analyzed by the measurement of superoxide and the corresponding sludge bioactivity by the measurement of TTC-DHA activity (Figure 5). TTC-DHA activity helps to identify the biological activity of anaerobic digestion, through the respiratory activity of the active microbial population. Surprisingly, on day 1 , the intracellular superoxide $\mathrm{s}\left[\mathrm{O}_{2}^{-}\right]$levels of the untreated digester were observed to be $81 \%$ higher than the hybrid $\left(\mathrm{MW}-\mathrm{H}_{2} \mathrm{O}_{2}\right)$ pre-treated digester (Figure 5a). A plausible explanation of this phenomenon could be the formation of more reactive hydroxyl radicals $[\mathrm{OH}]$ through Haber-Weiss type reaction (equation 5), in the treated digester that could account for the decrease in superoxide levels ${ }^{45}$.

$\mathrm{O}_{2}^{-}+\mathrm{H}_{2} \mathrm{O}_{2} \rightarrow \mathrm{OH}+\mathrm{HO}^{-}+\mathrm{O}_{2}$ equation (5)

The mechanism of Haber-Weiss reaction makes use of Fenton chemistry and the catalysis requires the presence of ferric ion in sludge. Mixed sludge being a source of various indigenous metal ions becomes a suitable target for Haber-Weiss reaction and accelerates the production of the highly reactive $\mathrm{OH}$ radicals ${ }^{46}$. The high s $\left[\mathrm{O}_{2}^{-}\right]$ levels in untreated digester in day 1 could be due to the oxidative stress experienced by aerobic living cells of activated sludge when they are exposed to anoxic conditions. In the subsequent days, $\mathrm{s}\left[\mathrm{O}_{2}^{-}\right]$decreases in untreated digester as the anaerobic microbial population takes over the entire digestion. A delayed increase in $\mathrm{s}\left[\mathrm{O}_{2}^{-}\right]$levels was observed in day 3 , in the treated digester similar to our previous reported results ${ }^{22}$, which confirms that the oxidative stress exerted by hybrid $\left(\mathrm{MW}-\mathrm{H}_{2} \mathrm{O}_{2}\right)$ pre-treatment has a prolonged effect in anaerobic digestion (Figure 5a). On comparison of the TTC-DHA activity, the treated digester exhibited $127 \%$ higher bioactivity during the initial thermophilic phase, which is concurrent with the increased methane production and process stability achieved in the treated digester (Figure 5b, 1 and 2a). On transfer to the mesophilic anaerobic digester, an improvement in methanogenic activity is observed in both the systems (Figure 5b). And $\mathrm{s}\left[\mathrm{O}_{2}^{-}\right]$levels are diminished during this peak methanogenesis (day 6 to 12) period in both the systems (Figure 5a). Moreover, an increasing $\mathrm{s}\left[\mathrm{O}_{2}^{-}\right]$trend is observed as the digestion comes to completion which is marked by decreasing TTC-DHA activity (Figure 5). Briefly, the generation of $\mathrm{s}\left[\mathrm{O}_{2}^{-}\right]$radicals are downregulated during active methanogenesis and observed to increase at dormant sludge activity.

\section{Conclusion}

Co-digestion of mixed waste sludge with $25 \% \mathrm{FVW}$ showed enhanced process stability and biomethanation compared to co-digestion with $50 \% \mathrm{FVW}$. Increased acidification observed in thermophilic phase I of codigestion (1:1) led to process instability and consequently, $33 \%$ less methane yield in subsequent phase II compared to co-digestion (3:1). Application of hybrid $\left(\mathrm{MW}-\mathrm{H}_{2} \mathrm{O}_{2}\right)$ pre-treatment significantly enhanced the methane production and quality in co-digestion (3:1). It increased the initial sludge solubilisation by $33 \%$ and facilitated 2.91-fold higher methane production in thermophilic phase-I compared to untreated digestion. Besides, the biogas quality was also improved with an average of $1.55 \mathrm{CH}_{4} / \mathrm{CO}_{2}$ ratio in the treated digester. The process stability was enhanced in treated digester with an average FOS/TAC of 0.26 in phase-II and helped achieve a 2.17-fold higher overall methane yield compared to the untreated digester. The improved process stability in the treated digester is mostly attributed to buffer capacity exhibited by biopolymers released during the treatment. A study on the oxidative status of the current anaerobic digestion revealed that superoxide radicals negatively correlate with sludge bioactivity. Further investigations on free radical production in anaerobic digestion could establish the mechanisms of free radical generation and their significance in anaerobic digestion. Overall these results reveal the high potential of co-digestion of FVW with mixed activated sewage sludge to enhance the performance of anaerobic digestion and overcome some of its fundamental operational limitations.

\section{References:}

1. Ghosh PR, Fawcett D, Sharma SB, Perera D, Poinern GEJ. Survey of Food Waste Generated by Western Australian Fruit and Vegetable Producers: Options for Minimization and Utilization. Food Public Heal . 2016;6(5):115-122. doi:10.5923/j.fph.20160605.02

2. Mata-Alvarez J, Macé S, Llabrés P. Anaerobic digestion of organic solid wastes. An overview of research achievements and perspectives.Bioresour Technol . 2000;74(1):3-16. doi:10.1016/S0960-8524(00)00023-7 
3. Ji C, Kong CX, Mei ZL, Li J. A Review of the Anaerobic Digestion of Fruit and Vegetable Waste. Appl Biochem Biotechnol . 2017;183(3):906-922. doi:10.1007/s12010-017-2472-x

4. Zhang Q, Hu J, Lee DJ. Biogas from anaerobic digestion processes: Research updates. Renew Energy . 2016;98:108-119. doi:10.1016/j.renene.2016.02.029

5. Ince O. Performance of a two-phase anaerobic digestion system when treating dairy wastewater. Water Res . 1998;32(9):2707-2713. doi:10.1016/S0043-1354(98)00036-0

6. Scano EA, Asquer C, Pistis A, Ortu L, Demontis V, Cocco D. Biogas from anaerobic digestion of fruit and vegetable wastes: Experimental results on pilot-scale and preliminary performance evaluation of a full-scale power plant. Energy Convers Manag . 2014;77:22-30. doi:10.1016/j.enconman.2013.09.004

7. Gómez X, Cuetos MJ, Cara J, Morán A, García AI. Anaerobic co-digestion of primary sludge and the fruit and vegetable fraction of the municipal solid wastes. Conditions for mixing and evaluation of the organic loading rate. Renew Energy . 2006;31(12):2017-2024. doi:10.1016/j.renene.2005.09.029

8. Di Maria F, Sordi A, Cirulli G, Gigliotti G, Massaccesi L. Co-treatment of fruit and vegetable waste in sludge digesters. An analysis of the relationship among bio-methane generation, process stability and digestate phytotoxicity. Waste Manag . 2014;34(9):1603-1608. doi:10.1016/j.wasman.2014.05.017

9. Bouallagui H, Torrijos M, Godon JJ, et al. Two-phases anaerobic digestion of fruit and vegetable wastes : bioreactors performance.Biochem Eng J . 2004;21:193-197. doi:10.1016/j.bej.2004.05.001

10. Ganesh R, Torrijos M, Sousbie P, Lugardon A, Steyer JP, Delgenes JP. Single-phase and two-phase anaerobic digestion of fruit and vegetable waste: Comparison of start-up, reactor stability and process performance. Waste Manag . 2014;34(5):875-885. doi:10.1016/j.wasman.2014.02.023

11. Wu Y, Wang C, Liu X, et al. A new method of two-phase anaerobic digestion for fruit and vegetable waste treatment. Bioresour Technol . 2016;211:16-23. doi:10.1016/j.biortech.2016.03.050

12. Kim M, Gomec CY, Ahn Y, Speece RE. Hydrolysis and acidogenesis of particulate organic material in mesophilic and thermophilic anaerobic digestion. 2003;24(9):1183-1190. doi:10.1080/09593330309385659

13. Mtz.-Viturtia A, Mata-Alvarez J, Cecchi F. Two-phase continuous anaerobic digestion of fruit and vegetable wastes. Resour Conserv Recycl . 1995;13(3-4):257-267. doi:10.1016/0921-3449(94)00048-A

14. Dinsdale RM, Premier GC, Hawkes FR, Hawkes DL. Two-stage anaerobic co-digestion of waste activated sludge and fruit/vegetable waste using inclined tubular digesters. Bioresour Technol . 2000;72(2):159-168. doi:10.1016/S0960-8524(99)00105-4

15. Carrere H, Antonopoulou G, Affes R, et al. Review of feedstock pretreatment strategies for improved anaerobic digestion: From lab-scale research to full-scale application. Bioresour Technol . 2016;199:386-397. doi:10.1016/j.biortech.2015.09.007

16. Shanthi M, Rajesh Banu J, Sivashanmugam P. Effect of surfactant assisted sonic pretreatment on liquefaction of fruits and vegetable residue: Characterization, acidogenesis, biomethane yield and energy ratio. Bioresour Technol . 2018;264:35-41. doi:10.1016/j.biortech.2018.05.054

17. Zhou Y, Takaoka M, Wang W, Liu X, Oshita K. Effect of thermal hydrolysis pre-treatment on anaerobic digestion of municipal biowaste: A pilot scale study in China. J Biosci Bioeng . 2013;116(1):101-105. doi:10.1016/j.jbiosc.2013.01.014

18. Liu X, Wang W, Gao X, Zhou Y, Shen R. Effect of thermal pretreatment on the physical and chemical properties of municipal biomass waste.Waste Manag . 2012;32(2):249-255. doi:10.1016/j.wasman.2011.09.027

19. Yu Y, Chan WI, Liao PH, Lo K V. Disinfection and solubilization of sewage sludge using the microwave enhanced advanced oxidation process.J Hazard Mater . 2010;181(1-3):1143-1147. 
doi:10.1016/j.jhazmat.2010.05.134

20. Eswari P, Kavitha S, Kaliappan S, Yeom IT, Banu JR. Enhancement of sludge anaerobic biodegradability by combined microwave-H2O2pretreatment in acidic conditions. Environ Sci Pollut Res . 2016;23(13):1346713479. doi:10.1007/s11356-016-6543-2

21. Eskicioglu C, Prorot A, Marin J, Droste RL, Kennedy KJ. Synergetic pretreatment of sewage sludge by microwave irradiation in presence of $\mathrm{H} 2 \mathrm{O} 2$ for enhanced anaerobic digestion. Water Res . 2008;42(18):46744682. doi:10.1016/j.watres.2008.08.010

22. Ambrose HW, Tse-Liang Chin C, Hong E, et al. Effect of hybrid (microwave-H2O2) feed sludge pretreatment on single and two-stage anaerobic digestion efficiency of real mixed sewage sludge.Process Saf Environ Prot . 2020;136:194-202. doi:10.1016/j.psep.2020.01.032

23. Ambrose HW, Philip L, Sen TK, Suraishkumar GK. The Effect of Combined Microwave and Hydrogen Peroxide Pretreatment on Sludge Characteristics and Oxidation Status of Waste Activated Sludge. In: Lefebvre B, ed. The Activated Sludge Process: Methods and Recent Developments . nova science publishers; 2019:105-141. https://novapublishers.com/shop/the-activated-sludge-process-methods-and-recentdevelopments/.

24. Liu J, Jia R, Wang Y, et al. Does residual $\mathrm{H} 2 \mathrm{O} 2$ result in inhibitory effect on enhanced anaerobic digestion of sludge pretreated by microwave-H2O2 pretreatment process? Environ Sci Pollut Res . 2017;24(10):90169025. doi:10.1007/s11356-015-5704-z

25. APHA. Standard Methods for the Examination of Water and Wastewater. American Public Health Association, Washington DC; 1999.

26. Dillalo R, Albertson OE. Volatile acids by direct tritation. Water Pollut Control Fed . 1961;33(4):356-365. https://www.jstor.org/stable/25034391.

27. Ghaly AE, Mahmoud NS. Optimum Conditions for Measuring Dehydrogenase Activity of Aspergillus niger using TTC. Am J Biochem Biotechnol . 2006;2(4):186-194. doi:10.3844/ajbbsp.2006.186.194

28. Sun S, Guo Z, Yang R, Sheng Z, Cao P. Study on the triphenyl tetrazolium chloride - dehydrogenase activity ( TTC-DHA ) method in determination of bioactivity for treating tomato paste wastewater.African J Biotechnol . 2012;11(27):7055-7062. doi:10.5897/AJB11.3548

29. Lowry OH, Nira J. Rosebrough, A. Lewis Farr, Randall RJ. Protein measurement with folin phenol reagent. J Biol Chem . 1951;193:265-275.

30. Masuko T, Minami A, Iwasaki N, Majima T, Nishimura SI, Lee YC. Carbohydrate analysis by a phenolsulfuric acid method in microplate format. Anal Biochem . 2005;339(1):69-72. doi:10.1016/j.ab.2004.12.001

31. Bouallagui H, Touhami Y, Ben Cheikh R, Hamdi M. Bioreactor performance in anaerobic digestion of fruit and vegetable wastes.Process Biochem . 2005;40(3-4):989-995. doi:10.1016/j.procbio.2004.03.007

32. Park ND, Thring RW, Helle SS. Comparison of methane production by co-digesting fruit and vegetable waste with first stage and second stage anaerobic digester sludge from a two stage digester. Water Sci Technol . 2012;65(7):1252-1257. doi:10.2166/wst.2012.004

33. Bolzonella D, Battistoni P, Susini C, Cecchi F. Anaerobic codigestion of waste activated sludge and OFMSW: The experiences of Viareggio and Treviso plants (Italy). Water Sci Technol . 2006;53(8):203-211. doi:10.2166/wst.2006.251

34. Di Maria F, Barratta M. Boosting methane generation by co-digestion of sludge with fruit and vegetable waste: Internal environment of digester and methanogenic pathway. Waste Manag . 2015;43:130-136. doi:10.1016/j.wasman.2015.06.007 
35. Liu X, Gao X, Wang W, Zheng L, Zhou Y, Sun Y. Pilot-scale anaerobic co-digestion of municipal biomass waste: Focusing on biogas production and GHG reduction. Renew Energy . 2012;44:463-468. doi:10.1016/j.renene.2012.01.092

36. Nkuna R, Roopnarain A, Adeleke R. Effects of organic loading rates on microbial communities and biogas production from water hyacinth : a case of mono- and co-digestion. J Chem Technol Biotechnol . 2019;94(January):1294-1304. doi:10.1002/jctb.5886

37. Wan C, Zhou Q, Fu G, Li Y. Semi-continuous anaerobic co-digestion of thickened waste activated sludge and fat, oil and grease. Waste Manag . 2011;31(8):1752-1758. doi:10.1016/j.wasman.2011.03.025

38. Mata-Alvarez J, Dosta J, Romero-Guiza MS, Fonoll X, Peces M, Astals S. A critical review on anaerobic co-digestion achievements between 2010 and 2013. Renew Sustain Energy Rev . 2014;36:412-427. doi:10.1016/j.rser.2014.04.039

39. Ravi PP, Lindner J, Oechsner H, Lemmer A. Effects of target pH-value on organic acids and methane production in two-stage anaerobic digestion of vegetable waste. Bioresour Technol . 2018;247(July 2017):96102. doi:10.1016/j.biortech.2017.09.068

40. Liu J, Tong J, Wei Y, Wang Y. Microwave and its combined processes: an effective way for enhancing anaerobic digestion and dewaterability of sewage sludge? J Water Reuse Desalin . 2015;5(3):264. doi:10.2166/wrd.2015.120

41. Lu L, Xing D, Liu B, Ren N. Enhanced hydrogen production from waste activated sludge by cascade utilization of organic matter in microbial electrolysis cells. Water Res . 2012;46(4):1015-1026. doi:10.1016/j.watres.2011.11.073

42. Mahdy A, Wandera SM, Qiao W, Dong R. Biostimulation of sewage sludge solubilization and methanization by hyper-thermophilic pre-hydrolysis stage and the shifts of microbial structure profiles. Sci Total Environ . 2019;699(September 2019):134373. doi:10.1016/j.scitotenv.2019.134373

43. Wang Y, Wei Y, Liu J. Effect of $\mathrm{H} 2 \mathrm{O} 2$ dosing strategy on sludge pretreatment by microwave-H2O2 advanced oxidation process. J Hazard Mater . 2009;169(1-3):680-684. doi:10.1016/j.jhazmat.2009.04.001

44. Liochev SI. Free radicals: How do we stand them? Anaerobic and aerobic free radical (chain) reactions involved in the use of fluorogenic probes and in biological systems. Med Princ Pract . 2014;23(3):195-203. doi: $10.1159 / 000357120$

45. Kehrer JP. The Haber-Weiss reaction and mechanisms of toxicity. Toxicology . 2000;149(1):43-50. doi:10.1016/S0300-483X(00)00231-6

46. Zhou X, Jiang G, Wang Q, Yuan Z. Role of indigenous iron in improving sludge dewaterability through peroxidation. Sci Rep . 2015;5:1-6. doi:10.1038/srep07516

\section{Tables and figures}

Table 1: Percentage composition of fruit and vegetable waste (FVW)

\begin{tabular}{ll}
\hline Component & Percentage \\
\hline Cabbage & 25 \\
Eggplant & 20 \\
Zucchini & 25 \\
Potato & 20 \\
Broccoli & 5 \\
Tomato & $<5$ \\
Nectarine & $<5$ \\
\hline
\end{tabular}


Table 2: Initial characterization of mixed activated sludge (MWAS) and fruit and vegetable waste (FVW)

\begin{tabular}{lll}
\hline Parameters & MWAS $^{\mathbf{a}}$ & $\mathbf{F V W}^{\mathbf{a}}$ \\
\hline $\mathrm{pH}$ & 6.6 & 5.0 \\
tCOD $(\mathrm{mg} / \mathrm{l})$ & $36566 \pm 94$ & $50800 \pm 81$ \\
$\mathrm{sCOD}(\mathrm{mg} / \mathrm{l})$ & $3500 \pm 163$ & $29100 \pm 216$ \\
TS $(\mathrm{mg} / \mathrm{l})$ & $27000 \pm 81$ & $37000 \pm 282$ \\
VS $(\mathrm{mg} / \mathrm{l})$ & $21333 \pm 94$ & $35810 \pm 94$ \\
VS $(\%$ TS $)$ & 79.01 & 96.78 \\
\hline
\end{tabular}

${ }^{\text {a }}$ Data are averages \pm standard deviation calculated from the results of triplicate measurements.

Table 3: Comparison of co-digestion (1:1) and (3:1)

\begin{tabular}{llll}
\hline Parameters & Co-digestion (1:1) & Untreated Co-digestion (3:1) & $\left(\mathbf{M W}-\mathbf{H}_{\mathbf{2}} \mathbf{O}_{\mathbf{2}}\right)$ treated co-digestiol \\
\hline $\mathrm{pH}$ & $4.3-7.4$ & $4.8-7.8$ & $5.1-7.8$ \\
VS reduction \% & $55 \pm 3$ & $63 \pm 1.5$ & $69 \pm 2.5$ \\
TS reduction \% & $51 \pm 3.2$ & $51 \pm 2$ & $56.2 \pm 1.7$ \\
COD removal \% & $73.8 \pm 1.2$ & $74.4 \pm 0.1$ & $81.6 \pm 0.2$ \\
Methane yield (ml/gVS) & 79 & 127 & 276 \\
Overall OLR (g/l/day) & 1.3 & 1 & 1 \\
\hline
\end{tabular}



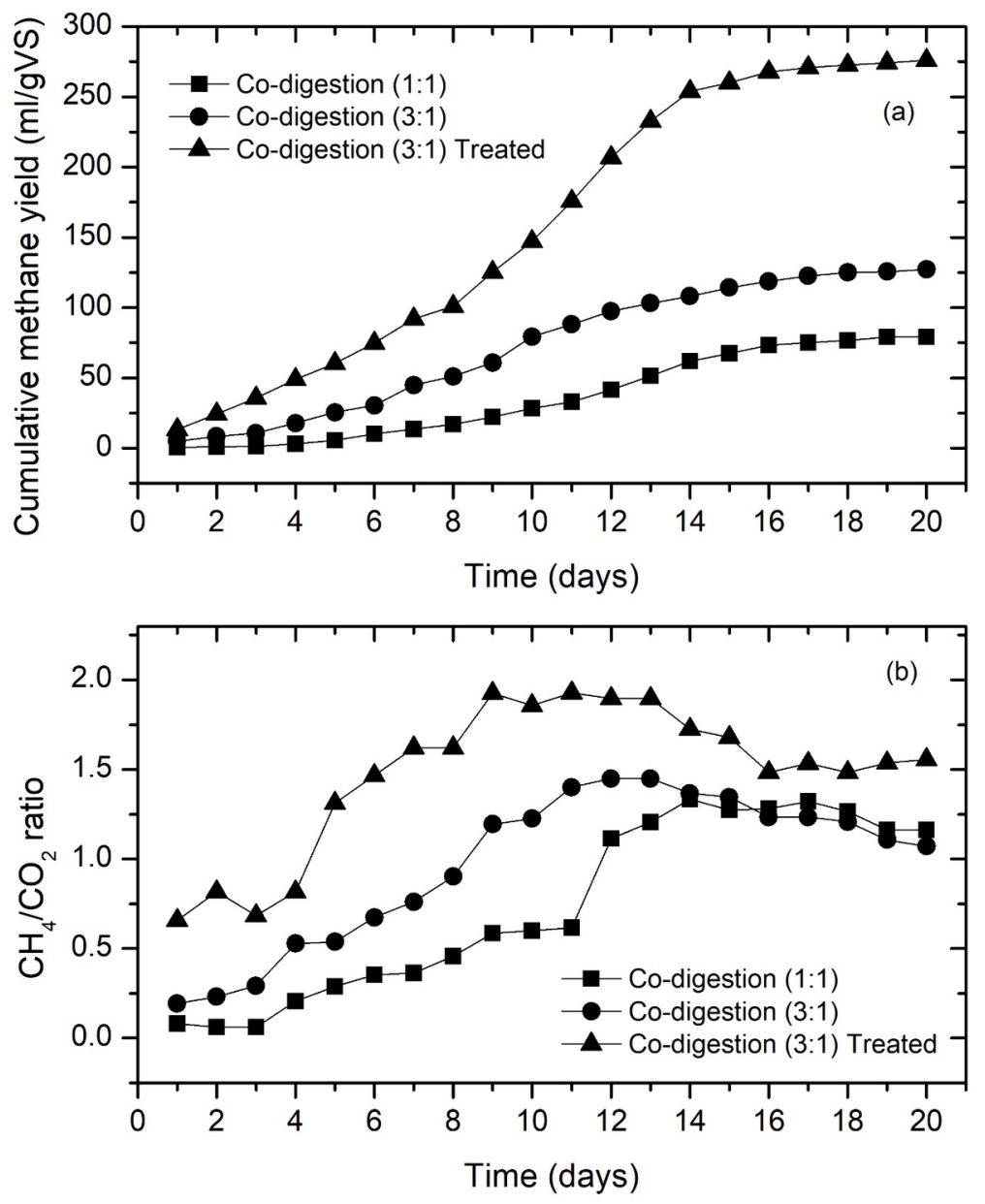

Figure 1: Evolution of (a) cumulative methane yield (ml/gVS) and (b) $\mathrm{CH}_{4} / \mathrm{CO}_{2}$ ratio in co-digestion (1:1MWAS:FVW), co-digestion (3:1- MWAS:FVW) and co-digestion (3:1- MWAS:FVW) treated with hybrid $\left(\mathrm{MW}-\mathrm{H}_{2} \mathrm{O}_{2}\right)$ pretreatment. 

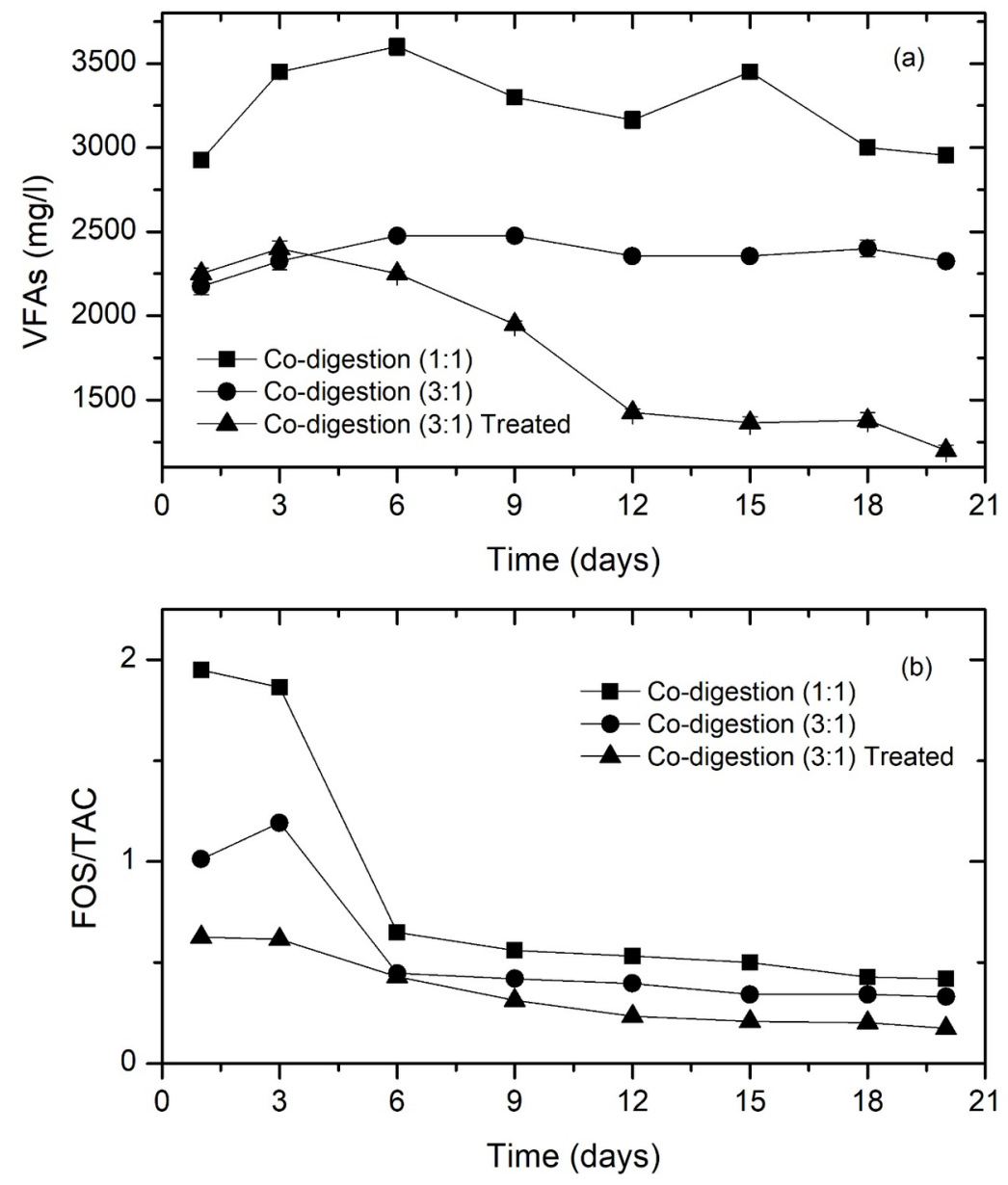

Figure 2: Comparison of acidification and digester stability in anaerobic co-digestion. Evolution of (a) VFAs $(\mathrm{mg} / \mathrm{l})$ and (b) FOS/TAC ratio in co-digestion (1:1- MWAS:FVW), co-digestion (3:1- MWAS:FVW) and co-digestion (3:1- MWAS:FVW) treated with hybrid $\left(\mathrm{MW}-\mathrm{H}_{2} \mathrm{O}_{2}\right)$ pretreatment. 

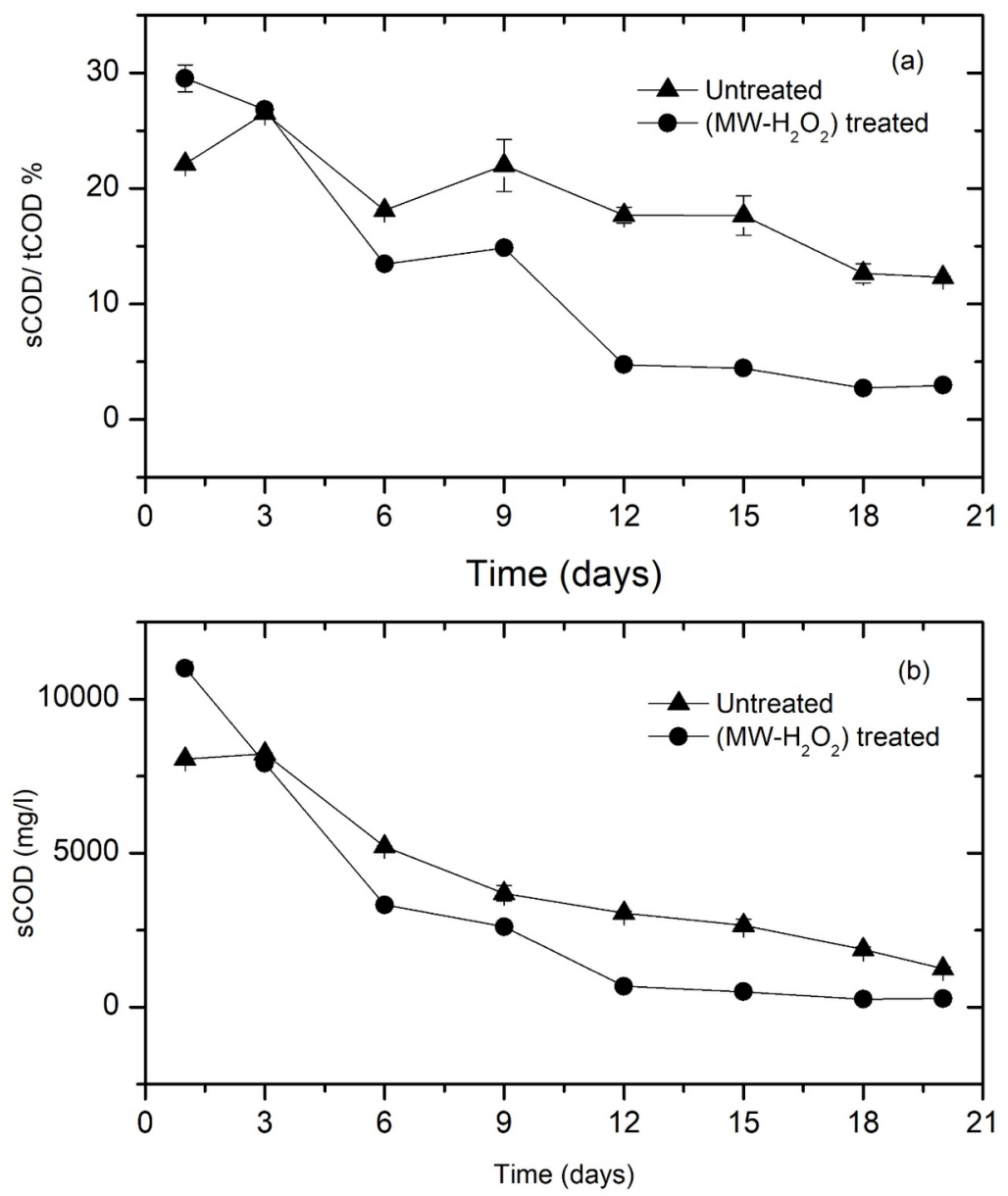

Figure 3: Comparison of COD solubilisation between untreated and hybrid $\left(\mathrm{MW}-\mathrm{H}_{2} \mathrm{O}_{2}\right)$ treated co-digestion (3:1- MWAS:FVW). 


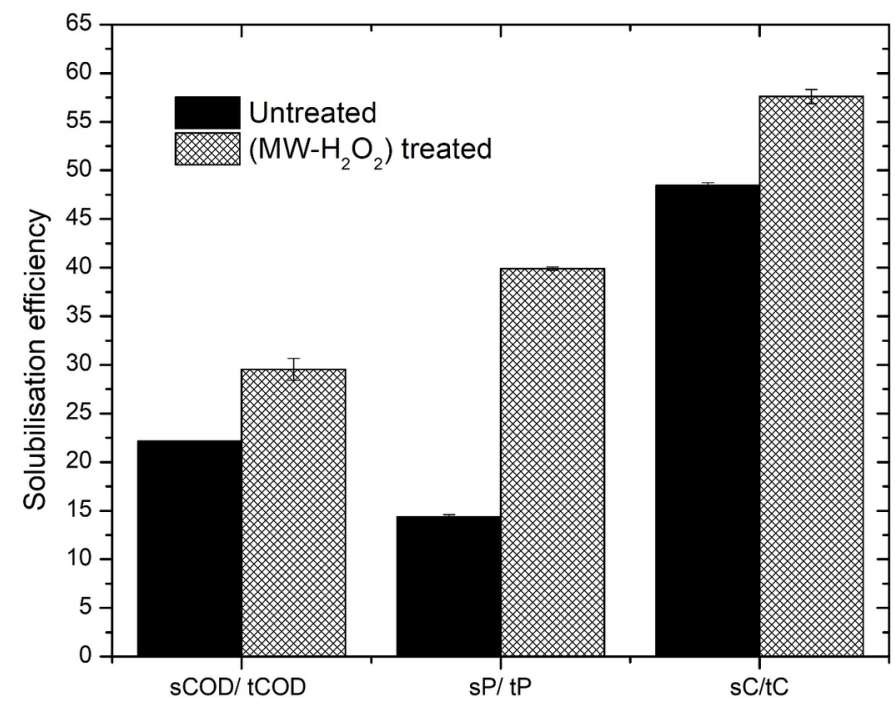

Figure 4: Comparison of COD solubilisation, protein and carbohydrate solubilization in untreated and hybrid $\left(\mathrm{MW}-\mathrm{H}_{2} \mathrm{O}_{2}\right.$ ) treated co-digestion (3:1- MWAS:FVW). sCOD/tCOD= ratio of soluble chemical oxygen demand to total chemical oxygen demand; $\mathrm{sP} / \mathrm{tP}=$ ratio of soluble protein to total protein; $\mathrm{sC} / \mathrm{tC}=$ ratio of soluble carbohydrate to total carbohydrate. 

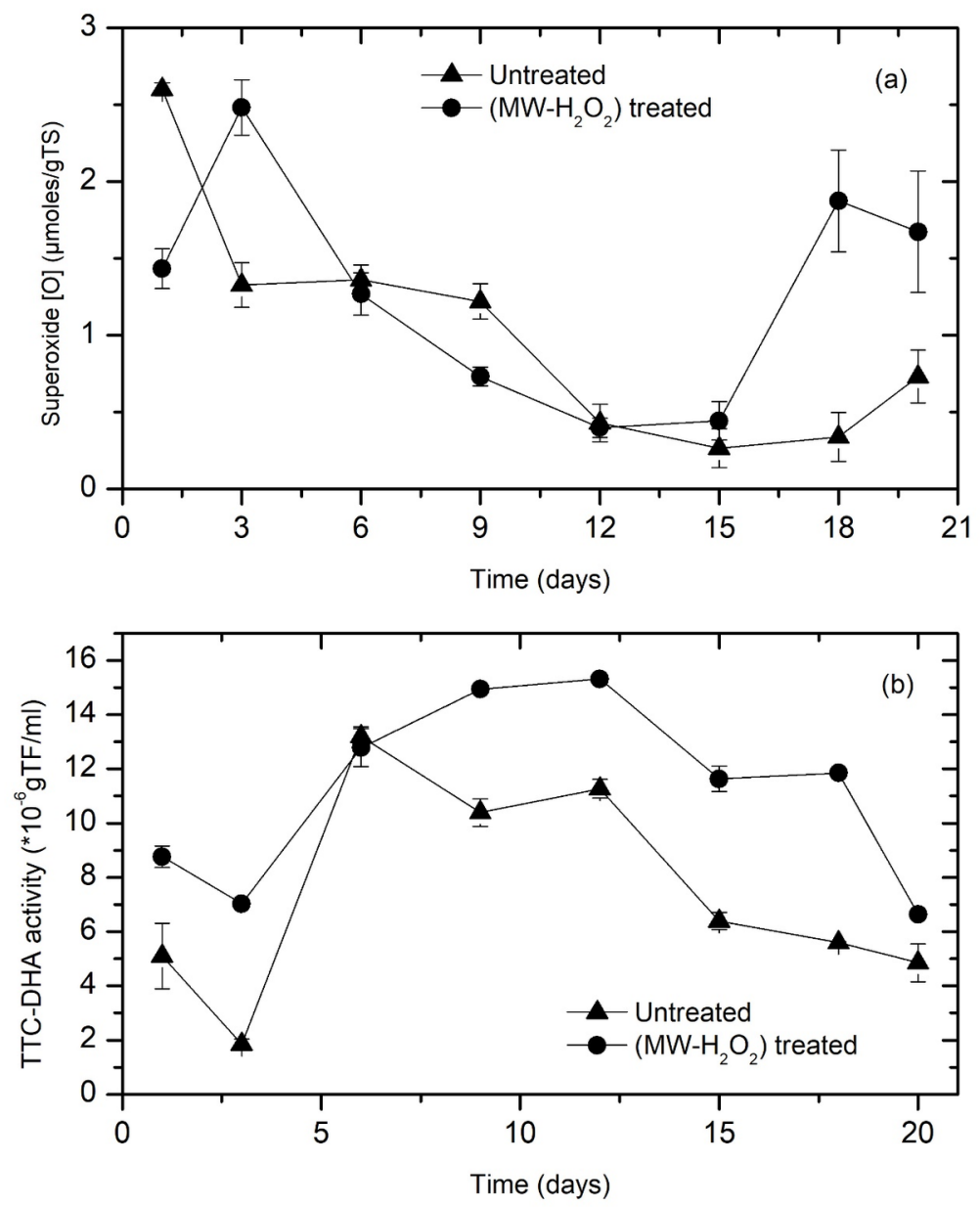

Figure 5: Comparison of (a) specific intracellular superoxides $\left[\mathrm{O}_{2}^{-}\right]$( $\mu$ moles/gTS) and (b) TTC-DHA activity $\left(\mathrm{x} 10^{-6} \mathrm{gTF} / \mathrm{ml}\right)$ in untreated and hybrid $\left(\mathrm{MW}-\mathrm{H}_{2} \mathrm{O}_{2}\right)$ treated co-digestion (3:1- MWAS:FVW)

\section{Hosted file}

Figure 1.tif available at https://authorea.com/users/302800/articles/432878-anaerobic-codigestion-of-mixed-activated-sewage-sludge-and-fruit-and-vegetable-waste-on-two-stagedigester-stability

\section{Hosted file}

Figure 2.tif available at https://authorea.com/users/302800/articles/432878-anaerobic-codigestion-of-mixed-activated-sewage-sludge-and-fruit-and-vegetable-waste-on-two-stagedigester-stability

\section{Hosted file}


Figure 3.tif available at https://authorea.com/users/302800/articles/432878-anaerobic-codigestion-of-mixed-activated-sewage-sludge-and-fruit-and-vegetable-waste-on-two-stagedigester-stability

\section{Hosted file}

Figure 4.tif available at https://authorea.com/users/302800/articles/432878-anaerobic-codigestion-of-mixed-activated-sewage-sludge-and-fruit-and-vegetable-waste-on-two-stagedigester-stability

\section{Hosted file}

Figure 5.tif available at https://authorea.com/users/302800/articles/432878-anaerobic-codigestion-of-mixed-activated-sewage-sludge-and-fruit-and-vegetable-waste-on-two-stagedigester-stability 